\title{
Digital Divide in Times of Pandemic among Teacher Education Students
}

\author{
Alfredo M. Esteban Jr. ${ }^{*}$, Mary Joy P. Cruz \\ College of Education, Nueva Ecija University of Science and Technology, Cabanatuan City, Philippines \\ Email: ^alfredomestebanjr@gmail.com, padiernosmaryjoy15@gmail.com
}

How to cite this paper: Esteban Jr. A.M. and Cruz, M.J.P. (2021) Digital Divide in Times of Pandemic among Teacher Education Students. Open Access Library Journal, 8: e7323.

https://doi.org/10.4236/oalib.1107323

Received: March 16, 2021

Accepted: April 12, 2021

Published: April 15, 2021

Copyright $\odot 2021$ by author(s) and Open Access Library Inc.

This work is licensed under the Creative Commons Attribution International License (CC BY 4.0).

http://creativecommons.org/licenses/by/4.0/

\section{Open Access}

\begin{abstract}
This study aimed to investigate the context of digital divide in teacher education institution (TEI) students during the COVID-19 pandemic setup. An online questionnaire was administered to 264 students from a state university in Nueva Ecija, Philippines. Spearman Rho Correlation was used as statistical tool with 5\% level of significance. The central finding of this study has confirmed the existence of digital divide as predicted by demographic factors such as residence, annual family income and parents' highest educational attainment. Significant differences were found to exist not only in access to the internet but also in mobile internet expenses and hours spent on the internet. This study provides a better understanding for further research to generate a more conclusive and generalizable result based on the strong starting points on digital divide found among higher education institution students.
\end{abstract}

\section{Subject Areas \\ Public Policy, Sociology, Technology}

\section{Keywords}

Digital Divide, COVID-19 Pandemic, Internet Access, ICT Usage

\section{Introduction}

The COVID-19 pandemic has created the largest disruption of education systems in history [1]. Because of this worldwide crisis, 190 countries across the globe [1] were forced to institute closures of school services [1] [2] [3] [4] that affected at least 1.6 billion students [5].

To cushion the effect of the school closures [4], academic institutions saw a pressing need to implement alternative educational and assessment strategies [6] such as distance education as the sole means for learning and instruction [7] and blended learning to include both virtual and in-person instruction [2]. In ensur- 
ing academic continuity, educational institutions abruptly shifted to online learning [3] [8] [9] [10]. But the current situation is not without any challenges as "COVID-19 has shone a spotlight on the digital divide" [11].

Based on the data of UNESCO, some 826 million students do not have access to a household computer while 706 million learners have no internet at home. Learners in the most marginalized groups, who don't have access to digital learning resources or lack the resilience and engagement to learn on their own, are at risk of falling behind [12]. In the advent of online education and the disparity of technological equipment available to the wealthy as compared to the poor students, instruction delivery will be inconsistent and unfair [11]. This crisis has exposed the many inadequacies and inequities in our education systems-from access to the broadband and computers needed for online education, and the supportive environments needed to focus on learning, up to the misalignment between resources and needs [12].

In Southeast Asia, a large segment of the population does not have access to the Internet and electronic devices [10]. Many people in Southeast Asia still cannot afford unlimited and stable Internet connection [13]. As a developing region, many students are from economically vulnerable families [10]. In as early as 2002, the Southeast Asian Ministers of Education Organization (SEAMEO) had been addressing the digital divide dilemma in the region by training and educating people through the SEAMEO Regional Centres [14]. The following interrelated factors contribute to the widening digital divide in Southeast Asia: economic development of the countries, availability of ICT infrastructure, level of education of the people and household income of family in the respected countries [14].

In the Philippines, the Commission on Higher Education (CHED) adopted and promulgated the guidelines on flexible learning delivery for implementation by all public and private higher education institutions to ensure safety of the Filipino learners during the coronavirus pandemic [15]. With in-person classes impossible, CHED put together distance learning options that include online platforms, offline modules, or a combination of the two, called blended or flexible learning [15]. But distance learning has made inequities, especially around the digital divide, more apparent than ever before and college students scramble to acquire digital devices and stable internet connection [16].

These scenarios give a glimpse of digital divide in an academic community in the Philippines. During this time of pandemic, digital divide is more than just "the gap between those who do and those who do not have access to new forms of information technology" [17] as it also encompasses a global issue that deals with the uneven distribution, access, and utilization of ICT [18] where certain parts of the population have substantially better opportunities than other parts of the population [19].

\subsection{Digital Divide}

Digital divide has significant implications for developing countries and it can 
cause segments or groups who have no or limited accessibility to these technologies to be denied of socioeconomic opportunities [20]. While the Philippines is deemed the social media capital of the world, millions are still left behind without proper internet access [21]. Since too much learning takes place online or requires gaining information technology skills, many students are disadvantaged as a result of the digital divide, and they are falling behind in their studies [22]. In this time of pandemic, "students may lack the technology they need to be successful in online learning" [23]. The shift to online classes, selflearning modules and television and radio programs has proven extremely challenging in a country of 108 million where less than a fifth of households have internet access and many lack mobile devices [24]. With the presence of digital divide, many are not fully benefitting from their education [25] [26]. Digital divide is a compound and multifaceted problem [27] as it falls along existing lines of socioeconomic inequality-those who are poorer and live in less affluent areas pay more for less reliable service and while smartphones are more prevalent across all socioeconomic groups, they're a poor alternative for broadband internet access for tasks like working from home or attending classes online [26]. Therefore, bridging the digital divide is more important than ever [28].

\subsection{This Study}

It is in this light that this study sought to investigate the circumstances of teacher education institution (TEI) students within the context of digital divide during the COVID-19 pandemic setup. With the occurrence of coronavirus pandemic, the landscape of educational system has changed and there is limited amount of published research in this particular situation. Therefore, this study provides additional evidence to the pool of literature on digital divide in the framework of pandemic and contributes important ideas to improve policy on technology use in educational institutions. Specifically, this study answered the specific questions below:

\subsection{Research Questions}

1) How may the profile of the students be described in terms of the following:

a) residence;

b) annual family income; and

c) parents' highest educational attainment?

2) What are the available ICT resources and their usage?

3) Is there a significant relationship between the students' profile variables and their available ICT resources use of ICT?

\section{Method}

The study used descriptive method to determine the incidence of digital divide in times of pandemic among teacher education students. It is also relational in 
terms of analyzing the relationship between the respondents' profile variables and use of ICT. For this reason, correlational and survey research models were used together.

\subsection{Sample}

This study used purposive sampling technique to constitute 264 students enrolled in Technology for Teaching and Learning classes at the College of Education, Nueva Ecija University of Science and Technology for the $1^{\text {st }}$ Semester of School Year 2020-2021. They were particularly chosen for this study as the course requires the use of technology among the students. From the demographic details of the respondents, $78 \%$ are females, $22 \%$ are males. Moreover, the respondents' age from 17 to 22 years old, majority of which are 19 year olds (44.70\%). Table 1 highlights the basic demographic characteristics of the participants to answer RQ1.

\subsection{Data Collection Tool}

This study used survey questionnaire as the data collection tool. The research team distributed the questionnaire via online survey system (Google Forms). The construction of the instrument was based on the Digital Divide Survey. This instrument was used in a comprehensive study to collect data across Trinidad

Table 1. Descriptive statistics for demographic variables.

\begin{tabular}{|c|c|c|c|}
\hline Variable & Coding & \multicolumn{2}{|c|}{ Distribution $(\mathrm{N}=264)$} \\
\hline \multirow[t]{2}{*}{ Residence } & Rural (Living in municipality) & \multicolumn{2}{|c|}{$165(62.50 \%)$} \\
\hline & Urban (Living in city) & \multicolumn{2}{|c|}{$99(37.50 \%)$} \\
\hline \multirow[t]{8}{*}{ Annual Family Income } & P 500,000 or more & \multicolumn{2}{|c|}{$1(0.38 \%)$} \\
\hline & P 450,000 - 499,999 & \multicolumn{2}{|c|}{$9(3.41 \%)$} \\
\hline & P 400,000 - P 449,999 & \multicolumn{2}{|c|}{$11(4.17 \%)$} \\
\hline & P 350,000 - P 399,999 & \multicolumn{2}{|c|}{$11(4.17 \%)$} \\
\hline & P 300,000 - P 349,999 & \multicolumn{2}{|c|}{$13(4.92 \%)$} \\
\hline & P 250,000 - P 299,999 & \multicolumn{2}{|c|}{$26(9.85 \%)$} \\
\hline & P 200,000 - P 249,999 & \multicolumn{2}{|c|}{$109(41.29 \%)$} \\
\hline & P 150,000 - P 199,999 & \multicolumn{2}{|c|}{$84(31.82 \%)$} \\
\hline \multirow[t]{7}{*}{$\begin{array}{c}\text { Highest Educational } \\
\text { Attainment }\end{array}$} & & Father & Mother \\
\hline & College Graduate & $85(32.20 \%)$ & $120(45.45 \%)$ \\
\hline & College Undergraduate & $126(47.73 \%)$ & $102(38.64 \%)$ \\
\hline & Vocational & $3(1.14 \%)$ & - \\
\hline & High School Graduate & $39(14.77 \%)$ & $27(10.23 \%)$ \\
\hline & High School Undergraduate & $9(3.41 \%)$ & $14(5.30 \%)$ \\
\hline & Elementary Graduate & $2(0.76 \%)$ & $1(0.38 \%)$ \\
\hline
\end{tabular}


and Tobago for the calculation and measurement of the digital divide [29]. Meanwhile, the present study asked the respondents to provide their demographic characteristics which particularly included residence, annual family income, and parents' highest educational attainment. The respondents were also asked to determine the ICT resources available to them as well as how they use such ICT resources in times of pandemic.

\subsection{Data Analysis}

Frequency counts, percentages, and Spearman Rho correlation were the bases for data analyses. The data obtained from Digital Divide Survey were transferred to computer and were analyzed with the SPSS 17.00 package program.

\section{Results and Discussion}

\subsection{Demographic Characteristics}

Table 1 shows the demographic characteristics of the respondents. The results show that majority (165 students, 62.50\%) live in municipalities (rural) while 99 (37.50\%) reside in the cities (urban).

In terms of annual family income, the data reveals that 109 (41.29\%) of the students fall under Php 200,000 - 249,999 (US\$ 4102 - 5128); Php 150,000 199,999 (US\$ 3077 - 4102) with 84 samples (31.82\%), is a distant second (Table 1). More than $17 \%$ of the students belong to a family whose income ranges from P 300,000 to P 500,000 . The results tell that the families where the students belong earn below the average annual family income, national ( $\mathrm{Php} \mathrm{313,000=}$ US\$ 6455.14) and regional (Php 384,000 = US\$ 7919.40), based on the 2018 Family Income and Expenditure Survey of the Philippine Statistics Authority [30].

The students were also asked regarding their parents' highest educational attainment and indicated that 205 parents (120 mothers and 85 fathers, 38.83\%) combined were able to finish tertiary education (Table 1). Meanwhile, the sum of parents who were college undergraduates reached 228 (43.18\%).

\subsection{ICT Resources and Usage}

\subsubsection{ICT Devices for Online Learning}

The survey shows that smartphone tops the list when it comes to new normal education as 202 students (76.52\%) used it as the main device of learning (Table 2). The findings validated the result that coronavirus pandemic prompted more people to go online and spend more time on smartphones [31] [32]. Higher education institutions should take note that implementing mobile-friendly content into programs may become an expected feature for many online students [33]. With classes shifting to virtual classrooms, students must be provided with activities and academic tasks that can be easily accessed through their mobile phones. Though the results also show that students can use other devices such as computer or tablet, still not all students have the capacity to go online because of 
Table 2. Descriptive statistics for ICT resources and usage.

\begin{tabular}{|c|c|c|}
\hline Variable & Coding & $\begin{array}{c}\text { Distribution } \\
(\mathrm{N}=264)\end{array}$ \\
\hline \multirow[t]{6}{*}{ ICT Device for Online Learning } & Laptop Computer & $34(12.88 \%)$ \\
\hline & Desktop Computer & $13(4.92 \%)$ \\
\hline & Smartphone & $202(76.52 \%)$ \\
\hline & Tablet & $5(1.89 \%)$ \\
\hline & Keypad Cellphone & $9(3.41 \%)$ \\
\hline & No gadget & $1(0.38 \%)$ \\
\hline \multirow[t]{4}{*}{ Internet Access at Home } & Wi-fi connectivity & $62(23.48 \%)$ \\
\hline & Mobile data & $147(55.68 \%)$ \\
\hline & Wired connection & $20(7.58 \%)$ \\
\hline & No internet. & $35(13.26 \%)$ \\
\hline \multirow[t]{5}{*}{ Weekly Internet Expenditure } & Less than Php 100 & $6(2.27 \%)$ \\
\hline & Php 100 - Php 150 & $110(41.67 \%)$ \\
\hline & Php 160 - Php 200 & $90(34.09 \%)$ \\
\hline & Php 210 - Php 250 & $38(14.39 \%)$ \\
\hline & More than Php 250 & $20(7.58 \%)$ \\
\hline \multirow[t]{5}{*}{ Daily Time Spent Online } & $1-5$ hours & $11(4.17 \%)$ \\
\hline & $5-10$ hours & $98(37.12 \%)$ \\
\hline & $11-15$ hours & $69(26.14 \%)$ \\
\hline & $16-20$ hours & $42(15.91 \%)$ \\
\hline & more than 20 hours & $44(16.67 \%)$ \\
\hline
\end{tabular}

limitations in their device, 9 (3.41\%) still use keypad cellphone and 1 (0.38\%) doesn't even own any gadget.

\subsubsection{Internet Access during COVID-19}

One hundred forty-seven (55.68\%) students used mobile data (Table 2) to attend their virtual classes. Because broadband is yet to become more accessible and affordable for Filipinos, Philippine internet use is highly mobile [34]. In the Philippines, mobile connections for January 2020 totaled to 173.2 million [35]. However, the Philippines lagged far behind other countries when it comes to mobile internet speed [35]. The nation has an average mobile internet download speed of $8.5 \mathrm{Mbps}$ and an average upload speed of $2.7 \mathrm{Mbps}$. With slow internet download and upload speed, students had to spend a large amount of money and time during this pandemic so that they would be able to access the internet and attend their virtual classes. What's saddening is that 35 students (13.26\%) still don't have internet access at home putting them at a disadvantage especially that lockdown prevents them from going out.

\subsubsection{Weekly Internet Expenditure}

Table 2 shows that 110 students (41.67\%) spent Php 100 - Php 150 weekly for 
their internet expenditure. Second were the 90 students (34.09\%) who would consume Php 160 - Php 200 while 58 (21.97\%) had more than Php 200 internet expenditure. The country's Internet infrastructure lags behind among those of contemporary developing countries in Asia, particularly in terms of Internet connectivity [36]. In 2015, the Philippines had a meager average Internet speed of $2.8 \mathrm{Mbps}$, placing the country at 104 among 160 countries [36].

When asked what are the factors affecting their ICT and internet use, the students provided the following: limited access or slow internet connection in an area, 43.63\%; financial capacity, 26.70\%; type of ICT device, $14.49 \%$; lack of technological skills, $6.11 \%$; no available device to use, $4.54 \%$; lack of parental support, $4.01 \%$; and power interruption, $0.52 \%$.

Slow internet connectivity persists to be the main problem among Filipino students as reflected by the results of this present study. Moreover, the findings of this study confirmed the result of a previous research that price would be the number one barrier for availing good internet speeds in the Philippines, since most people can't afford it [37].

\subsubsection{Daily Time Spent on Online Activities}

As can be seen from the table, the daily time spent online by 98 students (37.12\%) was 5 - 10 hours while others would extend up to 6 - 20 hours (69 students or $26.14 \%$ ) to accomplish their school requirements (Table 2). Internet users in the Philippines spend an average of 9 hours and 45 minutes per day online [35] [38]. With classes shifting to flexible learning, the time that students spent online has dramatically increased. The students identified the following school-related activities that needed internet connections: access learning groups (e.g., FB social learning group, group chats), 21.24\%; search for information, 19.85\%; download files (e.g., modules, PowerPoints, videos), 17.18\%; upload/submit files (e.g., email, assignments, projects), 15.29\%; answer written outputs (e.g., quizzes, essays), 11.76\%; create or watch videos, 9.45\%; and attend online meetings (e.g., through Zoom or Google Meet), 5.23\%.

\section{Relationship between the Profile Variables, Available ICT and Usage}

The purpose of this quantitative study was to determine the existence of digital divide as regards access and use of ICT of a purposeful sample of 264 teacher education institution (TEI) students. Spearman Rho Correlation was used as statistical tool with $5 \%$ level of significance. As can be seen in Table 3, the findings from this study showed that residence, annual family income, and parents highest educational attainment significantly predicted digital divide in ICT usage. These findings suggest that in terms of residence, living in rural area put the students at a disadvantage in accessing the internet $(\mathrm{p}=0.009)$. Having slow internet connection in their residence forces the students to have higher mobile data internet consumption $(\mathrm{p}<0.01)$ so they tend to spend more time online $(\mathrm{p}<0.01)$ doing school-related tasks. 
Table 3. Determinants of digital divide $(\mathrm{N}=264)$.

\begin{tabular}{llccc}
\hline & & $\begin{array}{c}\text { Access to } \\
\text { Internet }\end{array}$ & $\begin{array}{c}\text { Weekly } \\
\text { Internet } \\
\text { Expenditure }\end{array}$ & $\begin{array}{c}\text { Daily Time } \\
\text { Spent } \\
\text { Online }\end{array}$ \\
\hline \multirow{2}{*}{ Residence } & Correlation Coefficient & $0.161^{* *}$ & $0.645^{* *}$ & $0.723^{* *}$ \\
& Sig. (2-tailed) & 0.009 & 0.000 & 0.000 \\
Annual Family Income & Correlation Coefficient & $0.130^{*}$ & $0.649^{* *}$ & $0.849^{* *}$ \\
& Sig. (2-tailed) & 0.035 & 0.000 & 0.000 \\
Father's Highest & Correlation Coefficient & $0.193^{* *}$ & $0.537^{* *}$ & $0.539^{* *}$ \\
Educational Attainment & Sig. (2-tailed) & 0.002 & 0.000 & 0.000 \\
Mother's Highest & Correlation Coefficient & $0.177^{* *}$ & $0.174^{* *}$ & $0.227^{* *}$ \\
Educational Attainment & Sig. (2-tailed) & 0.004 & 0.005 & 0.000 \\
\hline$* * 0.01 * p<0.05$ & & & &
\end{tabular}

${ }^{* *} \mathrm{p}<0.01 ;{ }^{*} \mathrm{p}<0.05$.

Annual family income is also found to be a predictor of digital divide. Access to internet ( $\mathrm{p}=0.035$ ) is limited among students who belong to families with low income. Because of financial constraints, there is less budget allotted for internet expenditure $(\mathrm{p}<0.01)$ that hampers students' time $(\mathrm{p}<0.01)$ to accomplish online activities. Thus, students with higher family income have superior access to internet.

Another predictor of digital divide is found in the parents' highest educational attainment. The analysis indicates that internet access is influenced by the father's educational attainment $(\mathrm{p}$-value $=0.002)$ and mother $^{2} s$ educational attainment $(\mathrm{p}$-value $=0.004)$. The strength of relationships was found to be positive weak correlation. Therefore, the respondents whose parents are highly educated have greater internet access.

\section{Conclusions}

The present paper contributes to the digital divide literature as it sheds light on the dim areas for policymakers to consider to close the gap among students, especially in times of natural phenomenon like a pandemic. The central finding of this study has confirmed the existence of digital divide along the demographic factors such as residence, annual family income and parents' highest educational attainment. Significant differences were found to exist not only in access to the internet but also in mobile internet expenses and hours spent on the internet. The fact that more than $13 \%$ of students still don't have internet connections poses critical implications and necessitates deliberate policy formulation. It is also good to note that while mobile learning is progressing, there are students whose gadgets remain to be low-tech making it hard for them to access instructional materials uploaded online.

During pandemic, digital divide is higher and the negative effects brought by the COVID-19 on students become more evident. Though closing the digital divide among the students is an enormous challenge, this study provides relevant 
information to design plans of action that will level the playing field among students. To ensure that no one is left behind, all sectors of society must exert their best efforts to fill in the gap of the widening digital divide.

The findings of the study may serve as a strong starting point for other researchers in conducting further studies on digital divide among higher education institution students to generate more conclusive and generalizable results.

\section{Authors' Contributions}

Each author listed above has made substantial contributions to the conception, design of the study, manuscript or substantively revised it. The authors read and approved the final manuscript.

\section{Availability of Data and Materials}

All data of this research project is available with the authors and can be made available on requests if required.

\section{Conflicts of Interest}

The authors declare that they have no competing interests.

\section{References}

[1] United Nations (2020) Policy Brief: Education during COVID-19 and Beyond. https://www.un.org/development/desa/dspd/wp-content/uploads/sites/22/2020/08/s g_policy_brief_covid-19_and_education_august_2020.pdf

[2] Barrett, N. and Gerstenfeld, A. (2020) What Policymakers Need to Know Closing The Digital Divide. https://files.eric.ed.gov/fulltext/ED609752.pdf

[3] Lever, R. (2020) Pandemic Exposes 'Digital Divide' as Schools, Workplaces Close. https://phys.org/news/2020-03-pandemic-exposes-digital-schools-workplaces.html

[4] Azubuike, O.B., Adegboye, O. and Quadri, H. (2020) Who Gets to Learn in a Pandemic? Exploring the Digital Divide in Remote Learning during the COVID-19 Pandemic in Nigeria. International Journal of Educational Research Open, 2-2, Article ID: 100022. https://doi.org/10.1016/j.ijedro.2020.100022

[5] United Nations Educational, Scientific and Cultural Organization (2020) Startling Digital Divides in Distance Learning Emerge.

https://en.unesco.org/news/startling-digital-divides-distance-learning-emerge

[6] Pokhrel, S. and Chhetri, R. (2021) A Literature Review on Impact of COVID-19 Pandemic on Teaching and Learning. Higher Education for the Future, 8, 133-141. https://journals.sagepub.com/doi/pdf/10.1177/2347631120983481 https://doi.org/10.1177\%2F2347631120983481

[7] Young and Noonoo (2020) Education World Reacts to Coronavirus: The Latest Developments. https://www.edsurge.com/news/2020-03-05-education-world-reacts-to-coronavirus -the-latest-developments

[8] Puckett, C. (2020) Digital Adaptability: A New Measure for Digital Inequality Research. Social Science Computer Review. https://doi.org/10.1177\%2F0894439320926087 
[9] de Marcellis-Warin, N, Munoz, J.M. and Warin, T. (2020) Coronavirus and the Widening Educational Digital Divide: The Perfect Storm for Inequalities? https://cmr.berkeley.edu/2020/07/covid-education/

[10] Jalli, N. (2020) Lack of Internet Access in Southeast Asia Poses Challenges for Students to Study Online Amid COVID-19 Pandemic.

https://phys.org/news/2020-03-lack-internet-access-southeast-asia.html

[11] Whiting, K. (2020) SDI20: The UN is Pushing for Greater Digital CooperationThis Is Why.

https://www.weforum.org/agenda/2020/09/sdi20-united-nations-sdg-digital-cooper ation/

[12] Schleicher, A. (2020) The Impact of Covid-19 on Education: Insights from Education at a Glance 2020.

https://www.oecd.org/education/the-impact-of-covid-19-on-education-insights-edu cation-at-a-glance-2020.pdf

[13] The ASEAN Post (2018) ASEAN's Poor Mobile Internet Connectivity. https://theaseanpost.com/article/aseans-poor-mobile-internet-connectivity

[14] Pascual Jr., W. and Sadiman, A. (2002) SEAMEO's Approach in Bridging the Digital Divide in Southeast Asia.

https://www.seameo.org/vl/library/dlwelcome/publications/paper/delhi02.htm

[15] Commission on Higher Education (2020) CMO No. 4, s. 2020 Guidelines on the Implementation of Flexible Learning. Commission on Higher Education, Quezon City.

https://ched.gov.ph/wp-content/uploads/CMO-No.-4-s.-2020-Guidelines-on-the-I mplementation-of-Flexible-Learning.pdf

[16] Santos, A. (2020) In the Philippines, Distance Learning Reveals the Digital Divide. https://eu.boell.org/en/2020/10/06/philippines-distance-learning-reveals-digital-divi $\underline{\mathrm{de}}$

[17] Van Dijk, J.A. (2006) Digital Divide Research, Achievements and Shortcomings. Poetics, 34, 221-235. https://doi.org/10.1016/j.poetic.2006.05.004

[18] Talandron, M.M.P., Tautho, Y.C. and Tautho, C.C. (2016) Investigating the Digital Divide in a Rural Community in the Philippines. CMU Journal of Science, 20, $35-45$.

http://js.cmu.edu.ph/dev/posts/investigating-the-digital-divide-in-a-rural-communi ty-in-the-philippines

[19] Nielsen, J. (2006) Digital Divide: The 3 Stages. https://www.nngroup.com/articles/digital-divide-the-three-stages/

[20] Fong, M. (2009) Digital Divide: The Case of Developing Countries. Issues in Informing Science and Information Technology, 6, 471-478. https://doi.org/10.28945/1074

[21] PH Digital Justice Initiative (2021) Key Digital Justice Issues in the Philippines: The Digital Divide. [Photograph].

https://www.facebook.com/DGTLJusticePH/photos/a.170927434783337/206817904 $\underline{527623 /}$

[22] Auxier, B. and Anderson, M. (2020) As Schools Close Due to the Coronavirus, Some U.S. Students Face a Digital 'Homework Gap'. Pew Research Center. https://www.pewresearch.org/fact-tank/2020/03/16/as-schools-close-due-to-the-cor onavirus-some-u-s-students-face-a-digital-homework-gap/

[23] Ratledge, A., Dalporto, H. and Lewy, E. (2020) COVID-19 and Rural Higher Education Rapid Innovation and Ideas for the Future. 
https://www.mdrc.org/sites/default/files/Covid_Rural_HigherEd_final.pdf

[24] The Guardian (2021) The Shift to Online Classes, Self-Learning Modules and Television and Radio Programmes Has Proven Extremely Challenging in a Country of 108 Million Where Less than a Fifth of Households Have Internet Access and Many Lack Mobile Devices. [Photograph].

https://www.theguardian.com/artanddesign/gallery/2021/jan/18/mountain-trekking -to-catch-a-signal-online-learning-in-the-philippines?fbclid=IwAR0oCp2y7YESl-T FdIXZ9sHNVxliHPYFKRFxSE7_RpQM_MlfG5EGP4dUiS4

[25] Ritzhaupt, A.D., Cheng, L., Luo, W. and Hohlfeld, T.N. (2020) The Digital Divide in Formal Educational Settings: The Past, Present, and Future Relevance. In: Bishop, M.J., Boling, E., Elen, J. and Svihla, V., Eds., Handbook of Research in Educational Communications and Technology, Springer, Cham, 483-504.

https://link.springer.com/chapter/10.1007/978-3-030-36119-8_23

https://doi.org/10.1007/978-3-030-36119-8_23

[26] Porumbescu, G. (2020) The Digital Divide Leaves Millions at a Disadvantage during the Coronavirus Pandemic. The Conversation.

https://medicalxpress.com/news/2020-03-digital-millions-disadvantage-coronavirus -pandemic.html

[27] Chang, Y., Wong S.F. and Park, M.-C. (2014) A Three-Tier ICT Access Model for Intention to Participate Online: A Comparison of Developed and Developing Countries. Information Development, 32, 226-242.

https://doi.org/10.1177\%2F0266666914529294

[28] The United Nations Children's Fund (2021) These Children Are Going to Great Lengths to Access the Internet so They Can Continue Learning during COVID-19. But No Child Should Have to Study in a Cemetery, on a Roof or in the Pouring Rain. Bridging the Digital Divide Is More Important than Ever. [Facebook Status Update]. https://www.facebook.com/unicef/posts/10159030230699002

[29] Telecommunications Authority of Trinidad and Tobago (2013) The Digital Divide Survey Trinidad and Tobago. Telecommunications Authority of Trinidad and Tobago.

https://tatt.org.tt/Portals/0/documents/Digital\%20Divide\%20Survey2013_FINAL\%2 017-01-2014-reduced.pdf

[30] Philippine Statistics Authority (2018) 2018 Family Income and Expenditure Survey. Vol. 1. Philippine Statistics Authority, Lungsod Quezon.

https://psa.gov.ph/sites/default/files/FIES\%202018\%20Final\%20Report.pdf

[31] Rappler (2020) 13.4\% Jump in Phone WiFi Use in Philippines in First Week of Lockdown-OpenSignal.

https://www.rappler.com/technology/opensignal-report-smartphone-wifi-usage-cor onavirus-lockdown

[32] Khatri, H. (2020) Analyzing Mobile Experience during the Coronavirus Pandemic: Time on WIFI.

https://www.opensignal.com/2020/03/30/analyzing-mobile-experience-during-the-c oronavirus-pandemic-time-on-wifi

[33] Wiley (2020) The Use of Mobile Devices in Online Classrooms. https://edservices.wiley.com/mobile-devices-online-classrooms-use-demographic-h igher-education/

[34] Bueno, A. and Pacis, J. (2020) As COVID-19 Forces Life to Move Online, Who Is Left behind? CNN Philippines.

https://cnnphilippines.com/life/culture/2020/5/20/internet-access-pandemic.html 
[35] Fenwick, S. and Khatri, H. (2020) The State of Mobile Network Experience 2020: One Year into the 5G Era.

https://www.opensignal.com/sites/opensignal-com/files/data/reports/pdf-only/data2020-05/state_of_mobile_experience_may_2020_opensignal_3_0.pdf

[36] Salac, R.A. and Kim, Y.S. (2016) A Study on the Internet Connectivity in the Philippines. Asia Pacific Journal of Business Review, 1, 67-88. https://doi.org/10.20522/APJBR.2016.1.1.67

[37] Jennings, R. (2016) How the Philippines Got Asia's Worst Internet Service. https://www.forbes.com/sites/ralphjennings/2016/02/23/meet-asias-internet-laggard -the-philippines/?sh=5345cfa03df7

[38] Kemp, S. (2020) Digital 2020: The Philippines.

https://datareportal.com/reports/digital-2020-philippines 